\title{
ЦЕНТР ПЕРСПЕКТИВНЫХ ТЕХНОЛОГИЙ: ПЛАНЫ И ИННОВАЦИИ
}

\section{ADVANCED TECHNOLOGIES CENTER: PLANS AND INNOVATIONS}

\begin{abstract}
И.В.Яминский, 2,3, Ә.ф.-м.н., проф. МГУ имени М.В.Ломоносова физического и химического факультетов, генеральный директор Центра перспективных технологий, директор Энергоэффекттивных технологий (ORCID: 00000001-8731-3947), А.И.Ахметова ${ }^{1,2,3}$, инженер НИИФХБ имени А.Н.Белозерского МГУ, ведущий специалист Центра перспективных технологий и Энергоэффективных технологий (ORCID: 0000-0001-6363-8202) / yaminsky@nanoscopy.ru I.V.Yaminsky', 2,3, Doct. of Sc. (Physics and Mathematics), Prof., Director of Advanced Technologies Center, Director of Energy Efficient Technologies, (ORCID: 0000-0007-8737-3947), A.I.Akhmetoval, 2,3, Engineer of A.N.Belozersky Institute of Physico-Chemical Biology, Leading Specialist of Advanced Technologies Center and of Energy Efficient Technologies, (ORCID: 0000-0001-6363-8202)
\end{abstract}

\section{DOI: 10.22184/1993-8578.2020.13.1.54.58}

Получено: 10.01.2020 г.

Компании "Центр перспективных технологий" и "Энергоэффективные технологии" вошли в ведущий рейтинг самых высокотехнологичных и инновационных компаний "ТехУспех" по итогам 2019 года. Рейтинг "ТехУспех" - это инструмент поиска, мониторинга и продвижения перспективных быстрорастущих технологических компаний, которые обладают высоким потенциалом лидерства как на российском, так и на глобальном рынке.

The companies "Advanced Technologies Center" and "Energy Efficient Technologies" were included in the rating of the most high-tech and innovative companies "TechUspekh" following the results of 2019. The TechUspekh rating is a tool for searching, monitoring and promoting of the promising fast-growing technology companies that have high leadership potential both in the Russian and global markets.

y группы компаний "Центр перспективных технологий" и "Энергоэффективные технологии" несколько основных перспективных направлений: биосенсоры для молекулярной диагностики, сканирующая зондовая микроскопия, сканирующая капиллярная микроскопия, 3D-печать, обрабатывающие центры, разработка программного обеспечения для обработки данных в микроскопии. Все эти направления выросли на базе имеющейся компетенции по созданию атомно-силовых микроскопов серии "Скан" и "ФемтоСкан" [1]. ПО "ФемтоСкан Онлайн" успешно используется для обработки данных в микроскопии, например, в электронной, зондовой и любой другой не только в России, но и за рубежом $[2,3,4,5]$.

На базе капиллярного микроскопа мы развиваем 3D-биопечать. Печать осуществляется биомакромолекулами и биообъектами: ДНК, РНК, белками, липидами, вирусами и вирусоподобными частицами. Полученные результаты востребованы, в частности, в биосенсорных приложениях при изготовлении микрочипов и датчиков, локализованной иммобилизации биозондов на подложке для предотвращения стерических ограничений во время гибридизации мишени с зондами. Электрохимический контроль ионных потоков позволяет осуществлять высоколокализованную доставку частиц-прекурсоров и одновременно поддерживать динамическую обратную связь по изменению ионного тока для поддержания заданного расстояния от зонда до подложки. Это необходимо для формирования с помощью биомакромолекул высококачественного рисунка. Диаметр кончика капилляра в 30-50 нм для каждого канала позволяет 
изготавливать структуры различной формы с высоким аспектным отношением - L/d, где L - длина капилляра, $\mathrm{d}$ - средний диаметр. Этот подход обеспечивает универсальность и надежность метода сканирования и печати на наномасштабах с высоким пространственным разрешением.

Сканирующий капиллярный микроскоп позволяет отслеживать рельеф неровной и шероховатой поверхности, позволяет модифицировать и придавать требуемые свойства сложным трехмерным поверхностям. В качестве таких поверхностей могут выступать липидные и другие биологические мембраны, бактериальные биопленки, поверхности клеток и живых тканей. В качестве средств контроля используются методы просвечивающей и сканирующей электронной микроскопии, флуоресцентной оптической микроскопии, масс-спектрометрии, пьезокерамического взвешивания, атомных весов и др.

Несмотря на кажущуюся сложность, на курс по капиллярной микроскопии может записаться любой через Центр молодежного инновационного творчества "Нанотехнологии". Созданный при поддержке компании "Центр перспективных технологий" и правительства Москвы на базе физического факультета МГУ, ЦМИТ "Нанотехнологии" в этом году отмечает свое 6-летие. В декабре 2019 года ЦМИТ

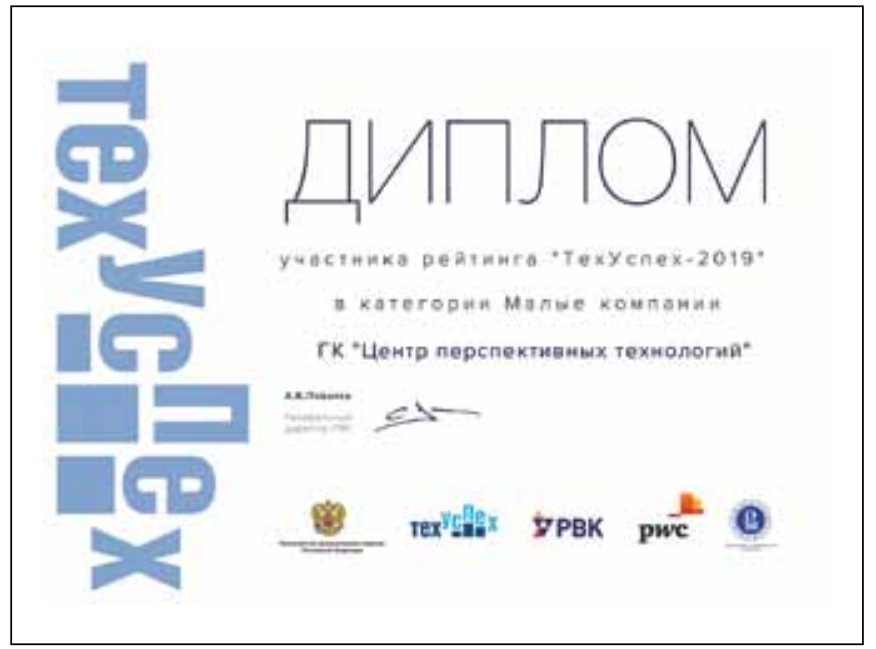

Рис.1. Диплом, подтверждающий участие компании "Центр перспективных технологий" в рейтинге "ТехУспех", за подписью генерального директора, председателя Правления АО "РВК" А.Б.Повалко

Fig.1. A diploma confirming the participation of the Advanced Technologies Center in the TechUspekh rating, signed by A.Povalko, General Director, Chairman of the Management Board of RVC JSC

"Нанотехнологии" принял участие в конгрессе "Наука +Бизнес", проводимом фондом "Иннопрактика". В рамках мероприятия был
$\mathbf{T}$ he group of companies "Advanced Technologies Center" and "Energy Efficient Technologies" has several main promising areas: biosensors for molecular diagnostics, scanning probe microscopy, scanning capillary microscopy, 3D printing, machining centers and development of software for processing data in microscopy. All these areas have grown on the basis of the existing competence to create atomic force microscopes of the Scan and FemtoScan series [1]. FemtoScan Online software is successfully used for data processing in microscopy, for example, in electron, probe and any other microscopy, not only in Russia but also abroad [2, 3, 4, 5].

Based on a capillary microscope, we are developing 3D bioprinting. Printing is carried out by biomacromolecules and biological objects: DNA, RNA, proteins, lipids, viruses and virus-like particles. The results obtained are in demand, in particular, in biosensor applications in the manufacture of microchips and sensors, localized immobilization of bioprobes on a substrate to prevent steric restrictions during hybridization of the target with probes. Electrochemical control of ion fluxes allows of highly localized delivery of precursor particles and at the same time maintains a dynamic feedback on the change in ion current to fix a given distance from the probe to the substrate. This is necessary for the formation of high-quality patterns using biomacromolecules. A 30-50 nm diameter capillary tip for each channel makes it possible to produce structures of various shapes with a high aspect ratio - L/d, where $\mathrm{L}$ is the length of the capillary, $d$ is the average diameter. This approach provides versatility and reliability of the scanning and printing method in nanoscales with high spatial resolution. A scanning capillary microscope allows tracking the relief of an uneven and rough surface, allows you to modify and add the required properties to complex three-dimensional surfaces. Such surfaces can be lipid and other biological membranes, bacterial biofilms, cell surfaces and living tissues. For control purposes, methods of transmission and scanning 


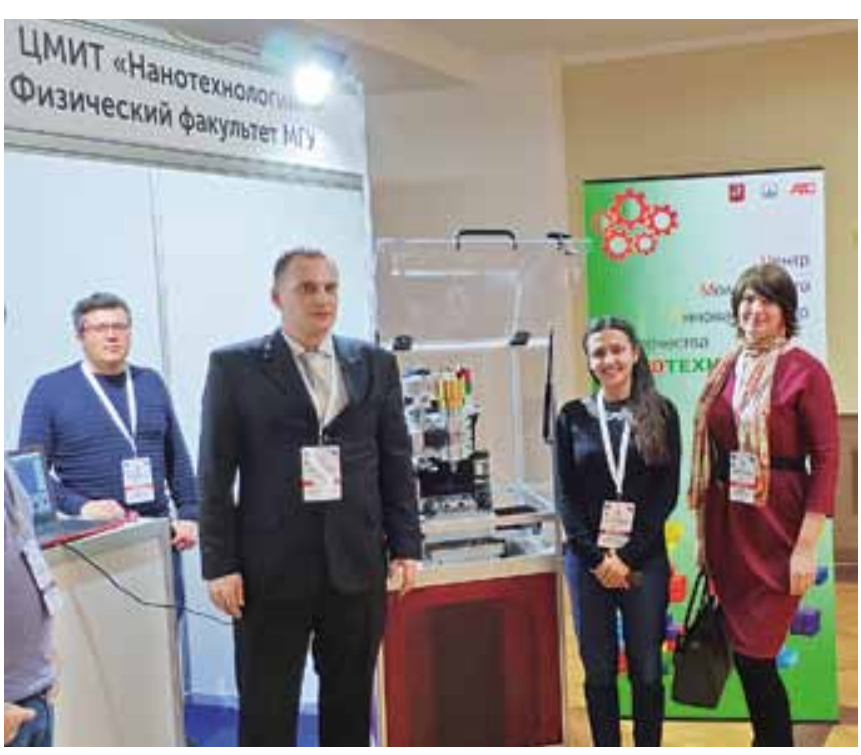

Pис. 2. Обрабатывающий центр АТС "Индустрия 4.0" на форуме "Наука + Бизнес", проводимом "Иннопрактикой". На фото - участники ЦМИТ "Нанотехнологии" демонстрируют станок Шуриной Наталье (Фонд содействия инновациям)

Fig.2. The ATC Industry 4.0 machining center at the forum "Science + Business", conducted by Innopraktika. In the photo, the participants of the TICC "Nanotechnologies" demonstrate the machine to Shurina Natalya (FASIE)

представлен фрезерный обрабатывающий центр АТС "Индустрия 4.0", разработанный при поддержке Фонда содействия инновациям $[6,7]$.

Станок спроектирован таким образом, что идеально подходит для прототипирования и мелкосерийного производства, а также для образовательных целей в школе и колледже.

Ключевые особенности обрабатывающего центра АТС "Индустрия 4.0":

- наличие автоматической смены инструмента;

- высокоскоростной шпиндель;

- уникальное программное обеспечение;

- защитный корпус;

- гофрозащита по всем осям;

- малые габариты и вес;

- привлекательная цена для обрабатывающего центра с автосменой инструмента 1150000 руб.

В Центре молодежного инновационного творчества "Нанотехнологии" регулярно проводятся обучающие курсы по направлению физического инжиниринга.

3D-проектирование в SolidWorks и механообработка. Цель программы - обучение проектированию в программе SolidWorks. Слушатели научатся выполнять построение 3D-деталей, сборку узлов и конструкций, создавать конструкторскую документацию, выбирать различные стратегии обработки материалов. В рамках курса слушатели работают с универсальным ПО для управления станками с ЧПУ.

Сканирующая зондовая микроскопия. Курс представляет собой широкий набор оборудования, обучающих программ и презентаций для экспериментального изучения бионаноскопии. Слушатели научатся работать со сканирующим зондовым микроскопом "ФемтоСкан", а также в программном обеспечении "ФемтоСкан Онлайн". Для прохождения electron microscopy, fluorescence optical microscopy, mass spectrometry, piezoceramic weighing, atomic balance, etc. are used. Despite the apparent complexity, anyone can enroll for a capillary microscopy course through the Nanotechnology YICC. Created with the support of the Advanced Technologies Creativity Center and the Moscow Government on the basis of the Physical Department of Moscow State University, YICC Nanotechnology celebrates its 6 th anniversary this year. In December 2019, Nanotechnology YICC took part in the congress
"Science + Business", organized by the Innopraktika Foundation. At the event, the ATC Industry 4.0 computer numerical center developed with the support of the FASIE $[6,7]$ was presented.

The machine is designed and ideally suited for prototyping and small-scale production, as well as for educational purposes in school and college.

The key features of the ATC Industry 4.0 Machining Center are:

- availability of the automatic tool change;

- high speed spindle;

- unique software;
- protective case;

- corrugated protection along all axes;

- small dimensions and weight;

- attractive price for a machining center with an automatic tool change - 1,150,000 rubles.

A general view of the milling processing center with an automatic tool change is shown in Fig.3.

The "Nanotechnology" YICC regularly conducts training courses in the field of physical engineering.

3D design in SolidWorks and machining. The goal of the program is design training in the 
итоговой аттестации предлагается провести сканирование образца и обработать полученные изображения.

Подробная информация о курсах расположена на сайте физического факультета МГУ в разделе дополнительного образования - http://dopobr.phys. msu.tilda.ws/page1745646.html.

Информация обо всех разработках компаний "Центр перспективных технологий" и "Энергоэффективные технологии" находится в открытом доступе на сайтах www.nanoscopy.ru и www.2ETechnologies.com.

Работы по изготовлению обрабатывающего центра выполнены при поддержке Фонда содействия инновациям (договор № 422ГРНТИС5/44715). Исследование по капияяярной микроскопии выполнено при финансовой поддержке РФФИ в рамках научного проекта № 17-52-560001. Авторы выражают искреннюю благодарность Департаменту предпринимательства и инновационного развития города Москвы и Министерству экономического развития Российской Федерации (договор № 8/3-63ин-16 от 22 августа 2016 года) за поддержку ЦМИТ "Нанотехнологии".

\section{ЛИТЕРATYPA / REFERENCE}

1. Yaminsky I.V. Ideas and Innovations, Factories and Plants // Nanoindustry. 2018. No. 1 (80). P. 84-86.

2. Akhmetova A.I., Yaminsky I.V. Software FemtoScan Online in solving problems of biology and medicine // Medicine and High Technologies. 2019. No. 1. P. 16-22.

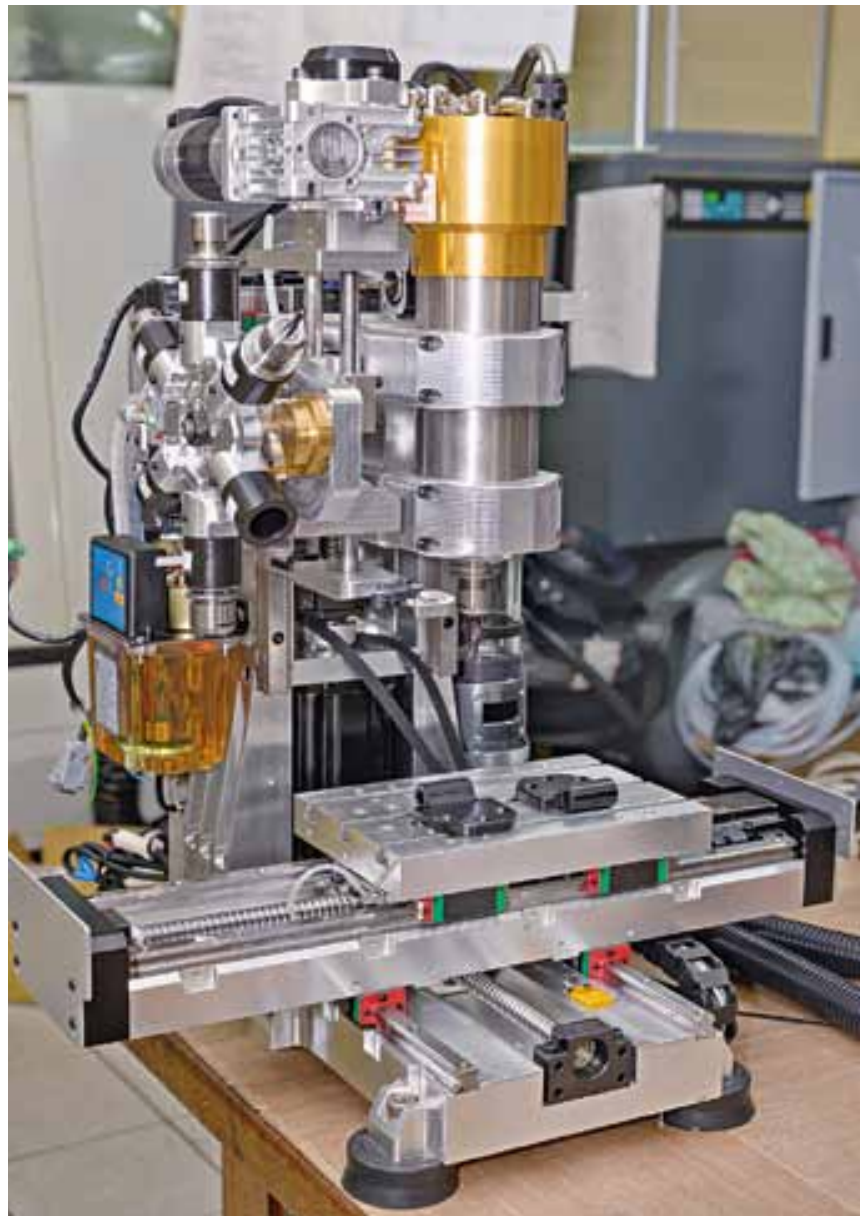

Рис.3. Общий вид механической системы обрабатывающего центра АТС "Индустрия 4.0"

Fig.3. ATC Industry 4.0 mechanical processing system. General view
SolidWorks program. Students will learn how to build 3D parts, assemble units and constructions, develop design documentation, and choose various strategies for processing materials. As part of the course, students work with universal software for controlling CNC machines.

Scanning probe microscopy. The course presents a wide range of equipment, training programs and presentations for the experimental study of bionanoscopy. Students will learn how to use the FemtoScan scanning probe microscope, as well as the FemtoScan Online software. To pass the final certification, it is proposed to scan a sample and process the resulting image.

Detailed information about the courses can be found on the website of the Physical Department of Moscow State University in the section of supplementary education - http:// dopobr.phys.msu.tilda.ws/ page1745646.html

Information on all the developments of the Advanced Technologies Center and Energy Efficient Technologies companies is publicly available on www.nanoscopy.ru and www.2ETechnologies.com.
The work on the manufacturing of the machining center was carried out with the support of the FASIE, Contract No. 422GRNTIS5/44715. Research on capillary microscopy was carried out with the financial support of the Russian Foundation for Basic Research in the framework of the scientific project No. 17-52560001. The authors express their sincere gratitude to the Department of Entrepreneurship and Innovative Development of the City of Moscow and the Ministry of Economic Development of the Russian Federation (Agreement No.8/3-63in16 dated 08.22.16) for their support of the YICC Nanotechnology. 
3. Filonov A.S., Yaminsky I.V., Akhmetova A.I., Meshkov G.B. FemtoScan Online! Why it? // Nanoindustry. 2018. T. 84. No. 5. P. 339-342.

4. Yaminsky I.V., Akhmetova A.I., Meshkov G.B. FemtoScan Online Software and Visualization of NanoObjects in High Resolution Microscopy // Nanoindustry. 2018. T. 11. No. 6 (85). P. 414-416.

5. Yaminsky I.V., Akhmetova A.I. FemtoScan Online software platform for biomedical appli- cations and materials science // Medicine and High Technologies. 2018. T. 2. P. 10-13.

6. Yaminsky I.V., Akhmetova A.I. ATC Industry 4.0: Basic s of Computer Numerical Control // Nanoindustry. 2019. T. 12. No. 6. P. 366-369.

7. Yaminsky I.V., Akhmetova A.I. Machining center with automatic tool change // Nanoindustry. 2019. T. 12. No. 5 (91). P. 276-279.

\section{АРТ-ПРОЕКТ "2020 $\rightarrow 2070 "$. МОСКВА - САНКТ-ПЕТЕРБУРГ - РОССИЯ}

Накануне Дня науки Фонд инфраструктурных и образовательных программ ГК РОСНАНО и Project Foundation запустили арт-проект "2020 $\rightarrow 2070 "$ ", направленный на популяризацию науки и высоких технологий, привлечение школьников, студентов и молодежи к карьерным перспективам в инновациях и технологиях и признанный лучшим популяризаторским проектом года.

Суть амбициозного проекта состоит в том, чтобы, по замыслу организаторов, объединить творческие усилия ученых, художников и визионеров для защиты человечества от культурного шока новых реалий и задать позитивные тренды. За круглым столом перед торжественным открытием арт-проекта состоялась дискуссия о вечном, жизни и смерти, новом понимании мироздания, симбиозе искусства и новейших достижений науки, изменениях климата и этике, развитии биоинженерии и искусственного интеллекта, автоматизации повседневного быта человечества и киборгизацией человека. Модератор круглого стола Михаил Слободинский, советник Председателя правления РОСНАНО, умело организовал "мозговой штурм", в котором сошлись председатель правления ОАО "РОСНАНО" Анатолий Чубайс, директор по региональному развитию ГЦСи Алиса Прудникова, ректор РХТУ им. Д.И.Менделеева Александр Мажуга, ректор МИСиС Алевтина Черникова, академик РАН, основатель и декан факультета биоинженерии и биоинформатики

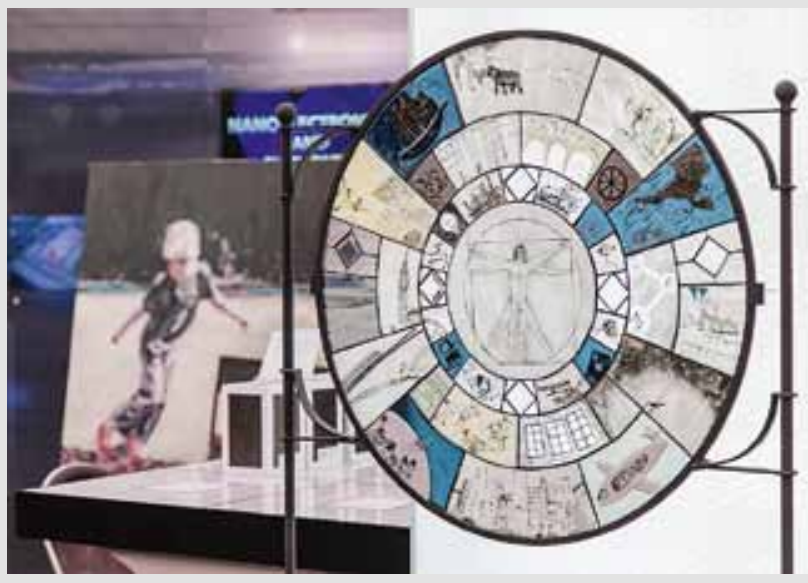

Рис.1. Яна Буланцева, "Изобретения"

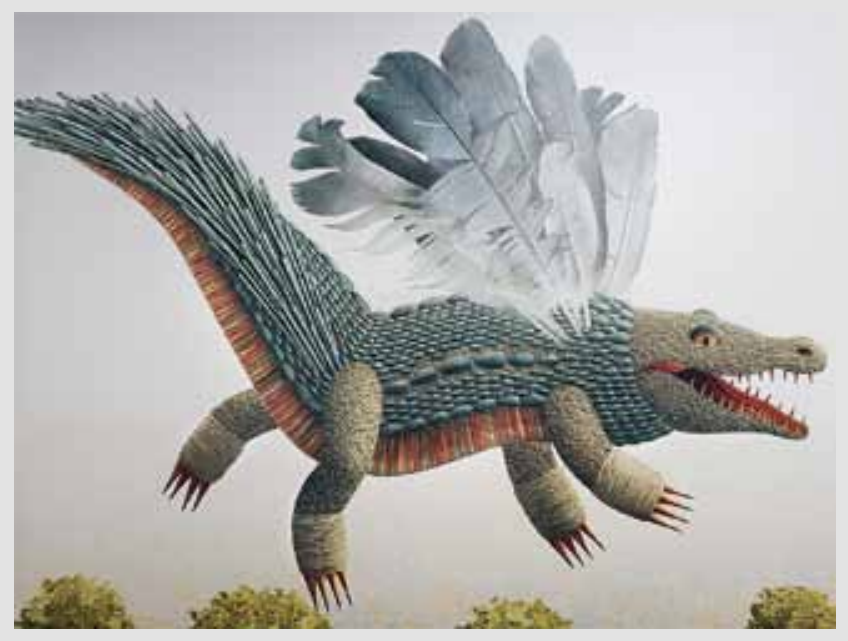

Рис.2. Александр Федоров "Пернатый змей"

МГУ им. Ломоносова Владимир Скулачев, директор Мультимедиа Арт Музея Ольга Свиблова и художники проекта, чьи работы находятся в ведущих российских и зарубежных музеях - от Третьяковки до Центра Помпиду: Иван Плющ, Александр Виноградов, Сергей Чобан и Георгий Острецов.

В арт-проекте были продемонстрированы работы Эрика Булатова "Лыжник", Гоши Острецова "Взрыв и эволюция", Жени Шефа "Бессмертие", Аристарха Чернышева РіО, Марины Звягинцевой "Нейрокод: восприятие искусства", Ольги Киселевой Chost Forest, Александра Савко "Билибин. Новые технологии", всего - более 70 произведений 20 российских художников.

Ведущие вузы Москвы в формате "открытого кода" предоставят свои площадки для 30 современных художников и смогут использовать их произведения в своей информационной и научно-популярной деятельности - в учебных заведениях будут проходить выставки, круглые столы и другие мероприятия, посвященные синтезу науки, технологии и искусства. Эстафету выставок начнет ниту "МИСиС" - об этом сообщила его ректор Алевтина Черникова, а далее арт-проект отправится в турне, в СанктПетербурга и далее по всей России. 


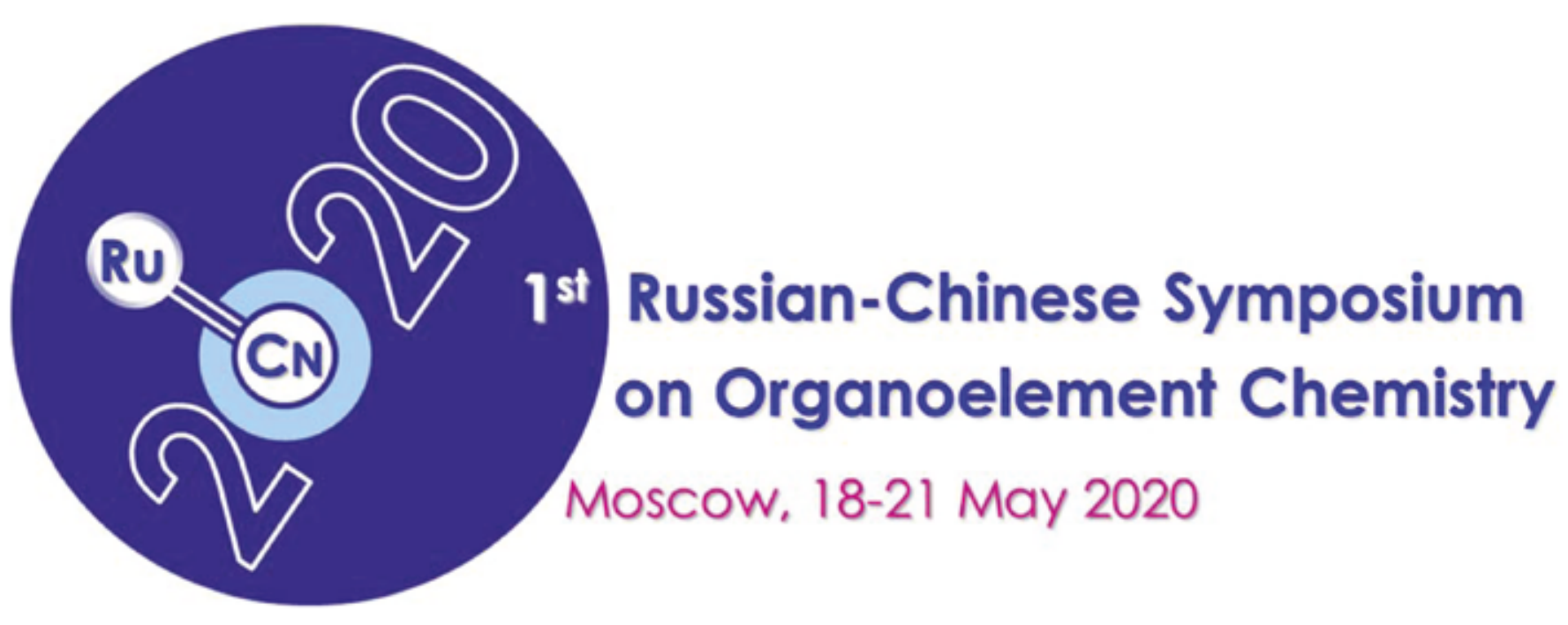

Глубокоуважаемые коллеги!

Институт элементоорганических соединений им. А.Н. Несмеянова РАН совместно с Государственной целевой лабораторией по элементоорганической химии Нанкайского университета (г. Тяньцзинь, Китай) приглашает Вас принять участие в 1-м Российско-Китайском симпозиуме по әлементоорганической химии. Симпозиум направлен на развитие устойчивого долгосрочного российско-китайского сотрудничества, расширение научного взаимодействия и обмена информацией о результатах исследований в различных областях элементоорганической химии; развитие внутрироссийской и международной коммуникации между научным, образовательным, и бизнес-сообществами, обсуждение возможности выполнения совместных проектов и создания совместной российско-китайской лаборатории по проблемам элементоорганической химии.

\section{Основные тематические направления Симпозиума:}

- элементоорганическая и координационная химия

- гомогенный и гетерогенный катализ

- элементоорганические полимеры и функциональные материалы

- супрамолекулярная химия

- элементоорганические и макромолекулярные соединения для химии материалов

Программой конференции предусмотрены пленарные доклады ведущих российских и китайских ученых, устные сообщения и стендовые сессии.

Актуальная информация о Симпозиуме и условиях участия - на сайте www.ineos.ac.ru

Будем рады видеть Вас среди участников Симпозиума!!! 